\title{
An Ombudsperson in the United Nations Security Council: a Paradigm Shift?*
}

\section{Un Ombudsperson en el Consejo de Seguridad de las Naciones Unidas: ¿un cambio de paradigma?}

\author{
Katalin Tünde Huber** \\ Alejandro Rodiles***
}

\begin{abstract}
Summary: I. Introduction. II. The Politico-Juridical Context. III. Preparing the Ground for Resolution 1904. IV. Resolution 1904 and the Ombudsperson. V. Some Initial Reactions. VI. Conclusion.
\end{abstract}

* Artículo recibido el 9 de diciembre de 2010 y aceptado para su publicación el de 29 de junio de 2011.

** Is a career diplomat and currently working at the Permanent Mission of Austria to the United Nations on counter-terrorism and sanctions issues. In this function she has been assisting the Chairman of the Security Council Committee concerning Al-Qaida and the Taliban during the period of 2009-2010. Previously, she has been working at the Austrian Permanent Representation to the European Union (EU). In her private capacity, she has been lecturing on EU decision-making at the Institute of European and International Business Law of the University St. Gallen, Switzerland.

*** Is currently the Legal Adviser to the Permanent Mission of Mexico to the United Nations. He is a doctoral candidate at the Humboldt-University of Berlin. He has been a lecturer of International and European Law at the National Autonomous University of Mexico (UNAM). The views expressed here are those of the authors and do not necessarily reflect the views of the Austrian Federal Ministry for European and International Affairs and/or of the Mexican Ministry of Foreign Affairs. 
RESUMEN: La presente contribución describe brevemente el contexto político-jurídico, así como las preparaciones y negociaciones que precedieron y resultaron en la adopción de la Resolución 1904 del Consejo de Seguridad de Naciones Unidas y en el establecimiento del Ombudsperson para el régimen de sanciones sobre Al-Qaeda y el Talibán. Si bien se reconoce que aún falta mucho por hacer para garantizar plenamente el respeto al debido proceso legal de los individuos y las entidades enlistadas, los autores argumentan que dicho cambio institucional es un logro destacado en el marco del emergente Estado de derecho global.

Palabras clave: Consejo de Seguridad de las Naciones Unidas, régimen de sanciones del Talibán y Al-Qaeda, derechos del debido proceso, legitimidad y eficacia de las sanciones, fragmentación del orden jurídico internacional, Estado de derecho global.

ABSTRACT: This contribution gives a brief account of the politico-juridical context, as well as of the preparations and negotiations that preceded and resulted in the adoption of United Nations Security Council resolution 1904 (2009) and the establishment of the Ombudsperson of the Al-Qaida and Taliban sanctions regime. While acknowledging that still much is needed in order to fully respect due process rights of listed individuals and entities, it is argued that this institutional change is a significant achievement in the frame of the emerging global rule of law.

Descriptors: United Nations Security Council, Al-Qaida and Taliban sanctions regime, Ombudsperson, due process rights, legitimacy and efficacy of sanctions, fragmentation of the international legal order, global rule of law.

RÉSUMÉ: Cette contribution décrit brièvement le contexte politique et juridique, ainsi comme les préparatifs et les négociations qui ont précédés et conduits à l'adoption de la résolution 1904 du Conseil de sécurité des Nations Unies et la mise en place de l'Ombusperson pour le régime de sanctions contre AlQaeda et les Taliban. Bien qu'on reconnais qu'il reste beaucoup à faire pour assurer le plein respect d'une sécurité du correcte procès judiciaire des individus et des entités énumérées, les auteurs argumentent que ce changement institutionnel est un réussite important dans le cadre du naissance État de droit mondial. Mots-clés: Conseil de Sécurité des Nations Unies, régime de sanctions pour Al-Qaeda et les Taliban, L'Ombudsperson, Droits de sécurité du correcte procès judiciaire, la légitimité et l'efficacité des sanctions, la fragmentation de l'ordre juridique international, état de droit mondial. 


\section{INTRODUCTION}

On 17 December 2009, the United Nations Security Council (SC) adopted resolution 1904, which renews the mandate of the Analytical Support and Sanctions Monitoring Team ("Monitoring Team"), i.e. the body of experts of the Committee established pursuant to resolution 1267 (1999) concerning Al-Qaida and the Taliban and associated individuals and entities. By doing so, the SC introduced a series of important changes to this sanctions regime, the most important of which being, without any doubt, the establishment of the Office of the Ombudsperson. ${ }^{1}$ The point is made by the authors of this contribution that despite all its shortfalls, the said resolution has improved the working methods of the 1267 Committee significantly, bringing it closer to the objective of granting "fair and clear procedures" to listed individuals and entities. ${ }^{2}$ Although this goal is not completed yet, resolution 1904, especially through the establishment of the institution of the Ombudsperson, constitutes a major step towards respect for the rule of law at the international level and is, arguably, a paradigm shift within the SC.

The present contribution does not pretend to make a detailed analysis of judicial decisions and academic proposals. It will instead focus on the general politico-juridical ambiance that motivated the establishment of the Ombudsperson (part II). It will then take a closer look at those initiatives and events in and around the United Nations (UN), which contributed to the preparations of the first draft and led to the

See United Nations Document (UN Doc), S/RES/1904 (2009), operative paragraph (op) 20 .

2 The term 'fair and clear procedures' was coined by the heads of State and government of the United Nations' (UN) member States in the 2005 World Summit Outcome. See UN Doc, A/RES/60/1 (2005), para. 109. It has been used since then in a number of UN resolutions and other documents when referring to due process rights of designated targets on sanctions lists. For the Security Council (SC), see, e.g., UN Doc, S/RES/1730 (2006), preambular paragraph (pp) 5; S/RES/1822 (2008), pp 12 and op 28; UN Doc, S/RES/1904 (2009), pp 9 and op 34; as well as the statements by the President of the SC, UN Doc, S/ PRST/2006/28, para. 5; and S/PRST/2010/11, para. 10. For the General Assembly and the Human Rights Council, see the resolutions on the protection of human rights and fundamental freedoms while countering terrorism: UN Doc, A/RES/64/168 (2010), op 9, and UN Doc, A/ $\mathrm{HRC} / \mathrm{RES} / 13 / 26$ (2010), op 14 and op 15. 
adoption of resolution 1904 (part III). Subsequently, the main features of this resolution will be presented (part $I V$ ). Based on first reactions by political and judicial bodies, an initial evaluation will be made (part $V$ ). By way of conclusion, the Ombudsperson will be put in the context of the emerging global rule of law (part $V I$ ).

\section{The Politico-Juridical CONTEXT}

Created in 1999 as a mechanism to monitor compliance with the aviation ban and financial sanctions imposed on the Taliban regime, ${ }^{3}$ the 1267 Committee has been subject to a series of changes over the past eleven years, developing into the most prominent subsidiary organ of the SC dealing with targeted sanctions. ${ }^{4}$ Individuals and entities pertaining to the Taliban and the Al-Qaida terrorist network, as well as those associated with them, regardless of their geographical location, are incorporated into a list of designated targets, the so called "Consolidated List”. ${ }^{5}$ These individuals and organizations are subject to a travel

3 See UN Doc, S/RES/1267 (1999), op 4 (on sanctions) and op 6 (on the establishment and mandate of the Committee).

4 On the evolution and the different types of SC sanctions, see Cortright, David et al., "The Sanctions Era: themes and trends in UN Security Council Sanctions since 1990", in Lowe, Vaughan et al. (eds.), The United Nations Security Council andWar, The Evolution of Thought and Practice since 1945, Oxford University Press, Oxford, 2008, at pp. 205-225. See also Matam, Farrall Jeremy, United Nations Sanctions and the Rule of Law, Cambridge University Press, Cambridge, 2007, pp. 106-132.

5 See UN Doc, S/RES/ 1617 (2005), op 1, and subsequent resolutions. Before Resolution 1617 , the Committee's group of experts already referred to it as the "consolidated list", at least since 2002; see, for example: UN Doc, S/2002/541, Report of the Monitoring Group established pursuant to Security Council resolution 1363 (2001) and extended by resolution 1390 (2002), 15 May 2002. The reason for calling it the "consolidated list" probably goes back to the fact that originally the SC referred only to "individuals and entities designated as being associated with Usama bin Laden, including those in the Al-Qaida organization”, when mentioning the list of designated targets (UN Doc, S/RES/1333 (2002), op 8). Op 2 of resolution 1390 (2002), which preceded the said report, relates the list to "Usama bin Laden, members of the Al-Qaida organization and the Taliban and other individuals, groups, undertakings and entities associated with them" (emphasis added). The consolidated list can be found at: http: / /www. un.org/sc/committees/1267/consolist.shtml (last visited 5 November 2010). 
ban, arms embargo and the freezing of their funds, financial assets and other economic resources. ${ }^{6}$

Once these sanctions are implemented at the national level, ${ }^{7}$ listed persons, natural and legal, suffer severe restrictions on the exercise of their property rights and are, to say the least, hampered in their freedom of movement. However, it is widely accepted that sanctions are a necessary tool in the maintenance and restoration of peace and security. ${ }^{8}$ There is thus a shared understanding that UN sanctions, as emergency measures under Chapter VII, concretely under Article 41 of the UN Charter, might impose restrictions under specific circumstances and on a temporary basis on the exercise of certain rights.

The problem is that what is meant to be of a temporary and exceptional nature has become a routine in the Council's work. The SC claims that sanctions are not of a punitive nature but of a preventive one, ${ }^{9}$ and that these measures are temporary restrictions in order to restore or maintain international peace and security. But it is precisely the indefinite duration of sanctions under the 1267 regime what has led some States, ${ }^{10}$ the UN High Commissioner for Human Rights (UN-

${ }^{6}$ For a detailed description of the 1267 regime, see, among others, Rosand, Eric, The Security Council's Efforts to Monitor the Implementation of Al Qaeda/Taliban Sanctions, American Journal of International Law (AJIL), Vol. 98, pp. 745-763; Cortright, David et al., supra note 4, at pp. 218-220. The website of the Committee provides a good overview; see: http: / / www. un.org/sc/committees/1267/index.shtml (last visited 5 November 2010). On SC sanction committees in general, see Matam Farrall, Jeremy, supra note 4, pp. 146-181.

In most States, the Consolidated List is not self-implementing. It requires additional legislative and/or administrative measures at the national level. An overview on how the list has been incorporated into domestic legal systems is provided by the reports that member States have to submit to the 1267 Committee according to resolution 1455 (2003), available at: http: / / www.un.org/sc/committees/1267/memstatesreports.shtml (5 November 2010).

8 See, e.g., UN Doc, S/RES/1730 (2006), pp2; as well as the last two Statements by the President of the Security Council on the rule of law: UN Doc, S/PRST/2006/28, para. 5; UN Doc, S/PRST/2010/11, para. 10.

9 In resolution 1617 (2005), pp 7, there is already a reference to the preventive nature of SC measures against terrorist activities. From 2006 onwards, the SC keeps reiterating that 1267 sanctions "are preventative in nature and are not reliant upon criminal standards set out under national law”. See UN, Doc, S/RES/1735 (2006) pp. 10; UN Doc, S/RES/1822 (2008), pp 13 and UN Doc, S/RES/1904 (2009), pp. 10.

${ }^{10}$ Liechtenstein has been one of the first States to make this point. See UN Doc, S/ PV.6217, 13 November 2009, p. 32. 
HCHR) and the Special Rapporteur on the promotion and protection of human rights and fundamental freedoms while countering terrorism ("Special Rapporteur") to question their character as preventive measures. ${ }^{11}$ According to these views, the freeze of assets and the travel ban have become rather permanent and thus amount to criminal punishments owing to the severity of the sanctions. It is important to note that these doubts have been recently acknowledged by the General Court of the European Union (GCEU), by stating that "the question of classification of the measures in question as preventative or punitive, protective or confiscatory, civil or criminal seems now to be an open one". ${ }^{12}$

The problem of the indefinite duration of temporary measures is certainly not limited to sanctions. It relates more broadly to the excessive use of Chapter VII powers by the SC, ${ }^{13}$ and to the Council's tendency to perpetuate the exception, especially in the context of the fight against terrorism. The 'state of emergency paradigm' ${ }^{14}$ underlies the whole design of counter-terrorism measures of the SC to which the $1267 \mathrm{Com}$ mittee is a key component, together with the 1373 Counter-Terrorism Committee (CTC) ${ }^{15}$ and, to a lesser extent given its primary nature as

1 See UN Doc, A/HRC/12/22, 2 September 2009, para. 42; UN Doc, A/63/223, 6 August 2008, para. 16, and UN Doc, A/65/258, 6 August 2010, paras. 52 \& 54.

12 GCEU, Judgment in case T-85/09, Yassin Abdullah Kadi vs. European Commission, 30 September 2010, para. 150, available at: http: / / curia.europa.eu (last visited 5 November 2010). It should be noted that the Court's considerations on this issue do not form part of the ratio decidendi.

13 Mexico has made this point in relation to the Security Council and the rule of law. See the statement by Ambassador Juan Manuel Gómez Robledo: UN Doc, S/PV.5474, 22 June 2006, p. 30 .

14 The literature on the 'state of emergency paradigm' in the frame of the international fight against terrorism is vast. One of the most representative works in this regard being: David Dyzenhaus, The Constitution of Law, Legality in a Time of Emergency, Cambridge, Cambridge University Press, 2006. For an accurate evaluation of this situation in specific relation to the SC counter-terrorism measures, see Andrea Bianchi, "Assessing the Effectiveness of the UN Security Council's Anti-terrorism Measures: The Quest for Legitimacy and Cohesion”, European Journal of International Law (EJIL), vol. 17, pp. 881-919, at 891-892.

15 The CTC does not entertain itself any list of targets. However, the general obligations established in resolution 1373 (2001) have given place to the enactment of national or regional lists designed to implement them. These lists face similar problems in regard to due process rights and have also led to a series of judicial decisions, which have been very important in the evolution of the case law related to the 1267 regime. See, inter alia, European Court of First 
a non-proliferation body, the Committee established pursuant to resolution 1540 (2004). ${ }^{16}$ Given that terrorism is perceived as a prevailing threat to international peace and security, ${ }^{17}$ there has been little need so far for the Council to rethink the exception approach, which allows for the prolonged use of extraordinary powers. In the case of sanctions imposed by the 1267 regime, this translates itself into long-lasting restrictions on the targets' rights. Since sanctions have become "smart", we are faced with the situation of the SC curtailing rights of legal entities and individuals, some of them of a fundamental nature, with an indefinite duration. Once an individual or legal entity is on the list, there is no time limit specifying their duration on it, except for the very uncertain indication that sanctions against them will remain in force as long as the Council considers the targeted category to which they belong or are associated with (e.g. the Taliban or Al-Qaida) a threat to international peace and security; a consideration which is mainly based on political criteria. ${ }^{18}$

This, among the secrecy of the 1267 Committee's decision-making process $^{19}$ and the difficulties for affected individuals and entities to

Instance (ECFI), Judgment in case T-284/08, People's Mojahedin Organization of Iran v Council, 4 December 2008, available at: http: / / curia.europa.eu (last visited 9 November 2010).

${ }^{16}$ Due to its mandate to prevent non-state actors from possessing (lato sensu) weapons of mass destruction (WMD), in particular for terrorist purposes, the 1540 Committee is also considered within this structure. See UN Doc, S/RES/1540 (2004), op 2.

17 Since resolution 1368 (2001) condemning the terrorist attacks of 9/11, the SC has categorized terrorist acts systematically as "threats to international peace and security". On this, see: Andrea Bianchi, supra note 14, at p. 890. It is also interesting to note that, somewhere in the mid-2000s, the SC completely abandoned the distinction between 'international terrorism' and other forms of 'terrorism'. Whereas resolutions 1373 and 1455 (2003) still referred to "international terrorism", the ministerial declaration annexed to resolution 1456 (2003) already declared that "terrorism in all its forms and manifestations constitutes one of the most serious threats to peace and security". This formula should prevail also within the 1267 regime; see: UN Doc, S/RES/1617 (2005), pp 2; UN Doc, S/RES/1735 (2006), p. 2; UN Doc, S/RES/1822 (2008), pp 2 and UN Doc, S/RES/1904 (2009), pp 2.

${ }_{18}$ In this context, it is interesting to draw the attention of the reader to the request of the Afghan government to de-list the names pertaining to the Taliban, a petition which was strictly related to the peace and reconciliation process in that country. See: The New York Times (NYT), U.N. Removes 5 Taliban From Its Sanctions List, 30 July 2010.

19 It is interesting to note in this regard that the 1267 Committee holds most of its sessions in closed meetings under an informal format. There are thus no official records of these meetings. 
access the decision-making body, has raised serious concerns among States and within civil societies worldwide. One only needs to recall here that until 2006, the only possibility for those on the Consolidated List to submit a de-listing request was through their State of nationality and/or residence, a measure announced in August 2002 via a press release of the SC and described a few months later in the first version of the Committee's Guidelines for the conduct of its work; two rather unknown documents outside the Council. ${ }^{20}$ It was not until 2005 that this very basic de-listing procedure, whereby the requesting government was encouraged to seek support from the designating government(s), was mentioned in a SC resolution. ${ }^{21}$

As a response to this situation, the United Nations took up the issue at the highest level during the plenary meeting of the $60^{\text {th }}$ General Assembly, in September 2005. In the World Summit Outcome, the heads of State and government of UN member States called upon "the Security Council, with the support of the Secretary-General, to ensure that fair and clear procedures exist for placing individuals and entities on sanctions lists and for removing them, as well as for granting humanitarian exemptions". ${ }^{22}$ It was also in September 2005, when the predecessor of the GCEU, the European Court of First Instance (ECFI), decided on the largely parallel Yusuf ${ }^{23}$ and $\mathrm{Kadi}^{24}$ cases.

As is widely known, the ECFI rulings did not have far reaching consequences on the 1267 regime mainly because of the limited scope the Court asserted with regard to the judicial review it could exercise over

20 See Press Release, UN Doc, SC/7478-AFG/203, 16 August 2002, and the Guidelines of the Committee for the Conduct of its Work, adopted on 7 November 2002, amended on 10 April 2003, 21 December 2005, 29 November 2006, 12 February 2007, 9 December 2008 and 22 July 2010, available at: http://www.un.org/sc/committees/1267/pdf/1267_guidelines.pdf (last visited on 9 November 2010).

${ }_{21}$ See UN Doc, S/RES/1617 (2005), op 5 and 18.

22 See supra note 2.

${ }^{23}$ ECFI, Ahmed Ali Yusuf and Al Barakat International Foundation v. Council of the European Union and Commission of the European Communities, Judgment in case T-306/01, 21 September 2005, available at: http: / / curia.europa.eu (last visited 9 November 2010).

${ }^{24}$ ECFI, Yassin Abdullah Kadi v. Council of the European Union and Commission of the European Communities, Judgment in case T-315/01, available at: http://curia.europa.eu (last visited 9 November 2010). 
the contested European regulations, and hence on relevant SC resolutions. ${ }^{25}$ Nevertheless, the Yusuf and Kadi decisions served as a warning to the SC, especially to the European permanent members, that the legality of 1267 sanctions could no longer be taken for granted, despite the "sovereignty of the Council". It has been rightly observed by one commentator that it is questionable, in the first place, if the ECFI did truly affirm the primacy of UN law, and consequently the "sovereignty of the Council", because it found it necessary to affirm this primacy through, inter alia, the provisions of the Treaty Establishing the European Community (TCE). ${ }^{26}$ Be that as it may, the fact that the ECFI finally did review the lawfulness of the relevant $\mathrm{SC}$ resolution vis-à-vis jus cogens is far more significant in the context of the politico-juridical ambiance that reigned in the years before the adoption of resolution 1904. It is true that the Court at the end found that jus cogens had not been breached through the European implementation of SC resolutions. However, this "extraordinary trick" of judicial review was a clear sign that courts and tribunals could become reluctant to show "complete deference" to the SC. ${ }^{27}$ In light of the final decision not yet rendered at that time by the European Court of Justice (ECJ), it becomes even clearer how this judicial incident affected deliberations within the SC in regard to sanctions, and specifically to the 1267 listing and de-listing procedures. Particularly the European permanent members of the SC began to find themselves caught between a rock and hard place as the European Union (EU) and the UN legal orders threatened to collide.

In June 2006, under the auspices of the Danish Presidency of the $\mathrm{SC}$, an open debate took place on "strengthening international law: rule

25 See Helmut Philipp Aust, Between Self-Assertion and Deference: European Courts and their Assessment of UN Security Council Resolutions, Anuario Mexicano de Derecho Internacional (AMDI), Vol. VIII, 2008, pp. 51-77, at pp. 57-64. It is important to recall that within the European Union (EU), 1267 sanctions are implemented through a multilevel approach. The list is incorporated into a Council Regulation (EC No. 881/2002, amended for the $101^{\text {st }}$ time by Commission Regulation (EC) No. 1190/2008 of 28 November 2008, Official Journal of the European Union, L 322, p. 25), which is binding upon and directly applicable in all EU member States. In addition, 16 EU member States have put in place a national mechanism which coexists with the EC regulation No. 881/2002. See supra note 7.

26 See Helmut Philipp Aust, idem, pp. 60-61.

27 See idem, pp. 61 and 74. 
of law and maintenance of international peace and security". During said debate a large number of delegations, including the five permanent members of the SC (P5), referred to the need to improving sanctions, in particular the Al Qaida and Taliban sanctions regime, towards greater transparency and fairness. ${ }^{28}$ In the resulting presidential statement, the Council stated to be "committed to ensuring that fair and clear procedures exist for placing individuals and entities on sanctions lists and for removing them, as well as for granting humanitarian exemptions [and reiterated] its request to the 1267 Committee to continue its work on the Committee's guidelines, including on listing and delisting procedures, and on the implementation of its exemption procedures...". ${ }^{29}$

During the debate a European member of the P5, namely France, proposed the creation within the UN Secretariat (Security Council Subsidiary Organs Branch) of a "focal point for receiving de-listing and exemption requests directly from the individuals". ${ }^{30}$ By the end of 2006, the SC adopted resolution 1730 establishing the focal point for all subsidiary organs of the SC dealing with targeted sanctions. ${ }^{31}$ This was certainly an important attempt to bring sanctions procedures closer to the requirements of the rule of law, an effort that was signalled, inter alia, by the explicit reference in the resolution to the presidential statement of June 2006. ${ }^{32}$ It is also fair to recall that improvements in the United $\mathrm{Na}$ tions' system are usually built up through a slow and burdensome stepby-step approach. Regarded from a politico-institutional and long-term perspective, the benefits of the establishment of the focal point should not be neglected. In practice, however, this institution soon developed into a sort of "UN mailbox", which basically limits itself to transmitting de-listing requests from listed individuals and entities to the Committees. ${ }^{33}$ And this should not surprise, as listing and de-listing procedures remained essentially the same.

28 See UN Doc, S/PV.5474.

29 UN Doc, S/PRST/2006/28, para. 5, 22 June 2006.

30 Supra note 28 , p. 18.

${ }^{31}$ See UN Doc, S/RES/1730 (2006), op 1 and Annex.

32 See idem, pp 1.

33 Although the Ombudsperson replaced the focal point, the former's mandate is circumscribed to the 1267 regime. For all other SC sanction committees the focal point is still in place. 
The amendments of 2006 did not change the circumstance that a subsidiary organ of a political body, conceived as guarantor of peace and security among States, is in charge of taking decisions, which affect individuals and private entities throughout the world in their legal rights and obligations. It is true, of course, that UN member States remain the direct addressees of the SC and that 1267 sanctions do not have a direct effect on individuals and legal persons. However, as has been rightly noted, "the Member State does not have any discretion as to whether it implements the sanctions or not or as to whom to sanction. The national level becomes the mere executing assistant of the Committee". ${ }^{34}$

The decisions of the Committee on each listing and de-listing request amount to a verdict of an individual's or private entity's status as a threat to international peace and security in light of their "association with" Al-Qaida, Usama bin Laden or the Taliban. ${ }^{35}$ Accepting a new entry to the list ${ }^{36}$ and/or assessing that an existing entry "remains appropriate", triggers coercive measures on the listed individuals and entities. These decision-making processes have been described as judicial or quasi-judicial functions. ${ }^{37}$ Perhaps more accurately, it can be said that they resemble administrative measures at the national level, where a public authority regulates "concrete, singular cases", ${ }^{38}$ affecting the legal situation of those outside the administration. Given the

${ }^{34}$ Feinäugle, Clemens A., "The UN Security Council Al-Qaida and Taliban Sanctions Committee: Emerging Principles of International Institutional Law for the Protection of Individuals?”, German Law Journal (GLJ), vol. 9, 2008, pp. 1513-1539, at p. 1521.

35 For these determinations the Committee applies the criteria set forth in resolution 1617 (2005) and reaffirmed in resolution 1904 (2009), which consist in "participating in the financing, planning, facilitating, preparing, or perpetrating of acts or activities by, in conjunction with, under the name of, on behalf of, or in support of; supplying, selling or transferring arms and related materiel to; recruiting for; or otherwise supporting acts or activities of Al-Qaida, Usama bin Laden or the Taliban, or any cell, affiliate, splinter group or derivative thereof". See UN Doc, S/RES/1617, op 2 \& 3, and UN Doc, S/RES/1904, op 2 \& 3.

36 See Guidelines of the Committee for the Conduct of itsWork, in particular No. 6, supra note 20.

37 See UN document, A/65/258, para. 57, supra note 11. See also Wet, Erika de, The Chapter VII Powers of the United Nations Security Council, Portland, Hart Publishing, 2004, pp. 352-354.

38 See supra note 34 , note 29 at p. 1520 . Feinäugle exemplifies this analogy with the German "Verwaltungsakt". It can be equally exemplified with the French "acte administratif" or the "acto administrativo" in Mexico. 
multiple layers involved in the imposition of 1267 sanctions, the whole process is probably best described as an act of "international composite administration". ${ }^{39}$ Paraphrasing von Bogdandy and Dann, a public authority, i.e. the Committee, operates at the global level ("upper level"), and a plurality of institutions, i.e. member States and, in the case of the EU, a regional body execute the former's decisions at the national or regional level, or both ("lower level"). ${ }^{40}$

The most critical shortfall of this international composite administrative regime is, without doubt, the absence of an effective remedy at the upper level. Designated sanction targets do not have a proper means at their disposal for challenging the acts adopted by the Committee that curtail their legal rights. Indeed, one of the axiomatic foundations of any legal system and the very essence of the principle of due process of law, ubi jus ibi remedium, has been simply ignored during the continuous construction of the 1267 system. The establishment of a focal point with no powers whatsoever to review the decisions of the Committee did not change this situation, which has given rise to significant concerns in the international community and, most importantly, to a series of judicial proceedings before regional and national courts, ${ }^{41}$ of which the so-called "Kadi I" case before the ECJ is arguably the most prominent one.

In its judgment of September 2008 on the appeals by Mr. Kadi and Al Barakaat International Foundation to the decisions of the former ECFI on the Yussuf and Kadi cases of 2005, the ECJ held that the ECFI erred in law when it sustained that the contested EC regulation, which was designed to give effect to a Chapter VII resolution, enjoyed immunity from jurisdiction in light of the principles governing the relationship

39 This point is made by Feinäugle, see supra note 34, at p. 1539. For the concept of "international composite administration”, see von Bogdandy, Armin y Dann, Philipp, International Composite Administration: Conceptualizing Multi-Level and Network Aspects in the Exercise of International Public Authority, GLJ, vol. 9, 2008, pp. 2013-2039, at pp. 2015-2017.

40 See idem, p. 2016.

${ }^{41}$ For an overview on national court decisions regarding SC sanctions, see Tzanakopoulos, Antonios, Domestic Court Reactions to UN Security Council Sanctions, in Reinisch, August (ed.), Challenging Acts of International Organizations before National Courts, Oxford, Oxford University Press, 2010, pp. 336, at pp. 54-76. 
between the UN legal order and community law. ${ }^{42}$ It further observed that such immunity would have constituted a "significant derogation from the scheme of judicial protection of fundamental rights laid down by the EC Treaty". ${ }^{43}$ Most significantly in the present context, the Court was very clear in regard to the insufficiency of the recent procedural improvements of the 1267 regime, which, in its view, did not offer guarantees of judicial protection. It clearly stated that "although it is now open to any person or entity to approach the Sanctions Committee directly, submitting a request to be removed from the summary list at what is called the 'focal' point, the fact remains that the procedure before that Committee is still in essence diplomatic and intergovernmental, the persons or entities concerned having no real opportunity of asserting their rights and that committee taking its decisions by consensus, each of its members having a right of veto". ${ }^{44}$ In this order, it simply appeared "unjustified" for the ECJ not to exercise judicial review "of the lawfulness of the EC regulations at stake in the light of the general principles of European Community law on fundamental rights". ${ }^{45}$

It is true that the ECJ did not directly review the lawfulness of SC resolutions, but limited itself to annulling the contested EC regulation in so far as it concerned Mr. Kadi and Al Barakaat International Foundation, on the grounds that the EU, while implementing SC resolutions, had not respected fundamental human rights, such as the right of defence, in particular the right to be heard, and the right to effective judicial review of those rights. In this context, the ECJ also found it necessary to note that the contested EC regulation could not be con-

${ }^{42}$ See Judgment of the Court (Grand Chamber) of 3 September 2008 - Yassin Abdullah Kadi, Al Barakaat International Foundation v Council of the European Union, Commission of the European Communities, United Kingdom of Great Britain and Northern Ireland, Joined Cases C-402/05 P and C-415/05 P, para. 327, available at: http: //curia.europa.eu (last visited 20 November 2010).

${ }^{43}$ Idem, para. 322.

${ }^{44}$ Idem, para. 323.

45 De Sena, Pasquale and Chiara Vitucci, Maria, The European Courts and the Security Council: Between Dédoublement Fonctionnel and Balancing of Values, EJIL, Vol. 20, 2009, pp. 193-228, at pp. 221-222. For further readings on the ECJ ruling of 2008, see the three replies to the said article by Gráinne de Búrca, André Nollkaemper and Iris Canor, in: EJIL, Vol. 20, 2009, pp. 853-887. 
sidered directly attributable to the UN, precluding thus reasons for denying jurisdiction ratione personae similar to those put forward by the European Court of Human Rights (ECHR) in the Behrami and Saramati cases. ${ }^{46}$ The Court nonetheless made the point, indirectly but clearly, that as long as the guarantees of judicial protection are not offered to the affected at the UN level (or the "upper level"), it could not remain silent and abstain from reviewing implementing measures at EU level (or the "lower level"). ${ }^{47}$ It further underlined in this regard that the primacy granted to the UN Charter within EU law "would not, however, extend to primary [EU] law, in particular to the general principles of which fundamental rights form part". ${ }^{48}$

It is not difficult to understand why the Kadi I judgment created such an enormous pressure on EU member States, including the two European permanent members of the SC, and why it played such an important role towards the adoption of resolution 1904. This landmark judgment basically announced that as long as the UN, concretely the SC sanction regimes, do not create an effective mechanism of protection and review of individual rights affected, however indirectly, by their decisions, it would continue to engage in judicial review of those acts designed to give effect to the former. This resembles the paradigmatic case law developed by the Federal Constitutional Court of Germany (Bundesverfassungsgericht) in another context of multilevel governance, namely that of European integration or, more precisely, in the frame of European multilevel constitutionalism. ${ }^{49}$ We are referring to the so-called Solange cases ("as long as"), ${ }^{50}$ especially the Solange I decision of 1974, whereby

${ }^{46}$ See supra note 42, paras. 310-314. For an interesting analysis of the Behrami and Saramati cases, see Kjetil Mujezinović Larsen, Attribution of Conduct in Peace Operations: The 'Ultimate Authority and Control'Test, EJIL, vol. 19, 2008, pp. 509-531.

47 See supra note 42, para. 326.

${ }^{48}$ Idem, para. 308.

49 For an early description and evaluation of the concept of 'multilevel constitutionalism' in the context of European integration, see Pernice, Ingolf, Multilevel Constitutionalism and the Treaty of Amsterdam: European Constitution-Making Revisited?, Common Market Law Review (CMLR), 36, 1999, pp. 703-750.

${ }^{50}$ This analogy has been made eloquently by Antonios Tzanakopoulos. For a comprehensive study of the development and impact of the Solange-argument in the frame of multilevel governance schemes, including the SC sanctions regimes, see Id., Judicial Dialogue in Multi- 
the Constitutional Court determined that "as long as" European Community law did not contain a catalogue of fundamental rights enacted by parliament, adequate in comparison to the fundamental rights' catalogue of the German Basic Law, it was entitled and obliged to exercise judicial review. ${ }^{51}$ This case law had a significant and concrete impact on European integration, particularly through the reaction of the former Court of Justice of the European Communities and its jurisprudential evolution on human rights. Now, it seems that its successor is assuming the role of the lower level's guarantor of fundamental rights vis-à-vis the administrator at the global level.

\section{PREPARING THE GROUND FOR RESOLUTION 1904}

The renewal of the mandate of the Monitoring Team, due by the end of 2009, was the much awaited next relevant Security Council resolution for the 1267 regime after the Kadi I case. The preparations for the resolution were manifold, and numerous stakeholders contributed to achieving further improvements of the sanctions regime. As of spring 2009, the wider public, including academia, non-governmental organizations (NGOs) and interested UN member States, raised awareness about the persistent shortcomings, mounted the pressure to address the challenges and proposed solutions to meet due process standards.

In May 2009, a group of like-minded States ${ }^{52}$ which had been strongly involved in the debate about targeted sanctions issued an informal

level Governance: The Impact of the Solange Argument, in: Ole Fauchald, Kristian \& Nollkaemper, André (eds.), Unity or Fragmentation of International Law: The Role of International and National Tribunals (forthcoming), available at: http://ssrn.com/abstract $=1407079$ (last visited 25 November 2010).

${ }^{51}$ For an overview of the Solange cases, see supra note 50. See also Rodiles Bretón, Alejandro, Hacia una Constitución europea, perspectivas jurídico-políticas, México, Porrúa, 2007, pp. 83-86.

52 As of November 2010, the group consists of the following States: Belgium, Costa Rica, Denmark, Finland, Germany, Liechtenstein, the Netherlands, Norway, Sweden and Switzerland. See http://www.norway-un.org/Statements/Security-Council/SC-On-the-al-Qaida-andTaliban-Sanctions-Committee (last visited 25 November 2010). 
options-paper ${ }^{53}$ to follow-up on their first discussion paper on the idea of establishing an expert panel assisting the sanctions Committee in the consideration of de-listing requests. ${ }^{54}$ The like-minded group acknowledged the steps taken by the SC to improve the procedures of various sanctions regimes, in particular by adopting resolutions 1730 (2006), 1735 (2006) and 1822 (2009), but stressed at the same time the need for further improvements to guarantee fundamental human rights, in particular by referring to recent judgments of national and regional courts. The group made several suggestions for measures to improve the listing and de-listing procedures and proposed biennial reviews of the Consolidated List. The group also reiterated its previous recommendation for an independent panel to review de-listing requests. This panel should have the competence to make non-binding recommendations, which the Committee could endorse or reject. It was suggested that the modalities of the panel could be elaborated, and that further consideration could be given to issues such as the effect of the panel's recommendations (advisory, quasi-binding, binding), the scope of the review and the composition of the panel. Furthermore, an expansion of the tasks of the focal point for de-listing was recommended, and the idea of a special advocate to discuss confidential information was put on the table.

As mentioned above, there were also a series of academic proposals, old and new, which were circulated among UN member States at that time, contributing thus significantly to the debate and preparations prior to the negotiations on the forthcoming resolution.

One of the first such studies is the paper on "targeted sanctions and due process" commissioned by the Legal Counsel of the UN and elaborated by Prof. Bardo Fassbender. ${ }^{55}$ The study first analyzed if and to what extent the UN, and specifically the SC, is bound to respect due process standards or — to use UN language_— "fair and clear procedures".

53 On file with the authors.

54 See UN document, A/62/891-S/2008/428.

55 Bardo Fassbender, Targeted Sanctions and Due Process, The responsibility of the UN Security Council to ensure that fair and clear procedures are made available to individuals and entities targeted with sanctions under Chapter VII of the UN Charter, Study commissioned by the United Nations Office of Legal Affairs, Office of the Legal Counsel, 20 March 2006, available at: http: / / www. unibw.de/voelkerrecht/unibw_folder.2007-08-08.1713991792 (last visited 28 November 2010). 
While acknowledging recent developments in the field of customary international law, and the importance that general principles of law about due process increasingly have for international organizations, it made clear that "the principal source of human rights obligations of the United Nations is the UN Charter [and that] all UN organs are bound to comply with the rules of the Charter as the constitution of the United Nations". ${ }^{56}$ Accordingly, the point was made that "whenever the Organization is taking action that adversely affects, or has the potential of adversely affecting, the rights and freedoms of individuals", ${ }^{57}$ all organs of the UN are obliged to respect human rights and fundamental freedoms, including rights of due process. After observing that the exact scope of those "Charter-based due process rights" is not "generally predefined" and that specific adjustments in the case of particular sanctions regimes may be needed, the SC was recommended to guarantee to the affected individuals the right to be informed, the right to be heard, the right of being advised and represented, and the right to an effective remedy "before an impartial institution or body previously established". ${ }^{58}$

In October 2009, the Watson Institute for International Studies updated its "White Paper" of 2006. ${ }^{59}$ The new report ${ }^{60}$ gave an overview of the legal and litigation-related challenges, developments and procedural improvements, and analyzed various options for review-mechanisms, such as a new Security Council Subgroup, an expanded role for the Monitoring Team, an impartial advisory panel or an independent judicial panel. The idea of an Ombudsperson who could make recommendations, previously advanced by Denmark ${ }^{61}$, was also considered. The report also contained a number of recommendations for procedural reforms within the Committee and for measures at the national and UN levels.

56 Ibidem, pp. 24 and 25.

57 Ibidem, p. 27.

58 Ibidem, p. 28.

59 Bierstecker, Thomas and Eckert, Sue, Strengthening Targeted Sanctions Through Fair and Clear Procedures - White Paper,Watson Institute, Brown University, 2006.

${ }^{60}$ Bierstecker, Thomas and Eckert, Sue, Addressing Challenges to Targeted Sanctions - An Update of the "Watson Report", Watson Institute, Brown University, The Graduate Institute, Geneva, UNO Academia, 2009.

${ }^{61}$ See infra note 66 and accompanying text. 
An additional important contribution was made by the Fourth Freedom Forum and the Kroc Institute, published in November 2009. ${ }^{62}$ The paper assessed the focal point's procedure and discussed possibilities of expanding its role, as well as that of the Monitoring Team. Furthermore, it analyzed more deliberative and robust de-listing and listing procedures, including fixed terms for listing, an impartial review panel, reviewing sensitive information, a smaller and more accurate Consolidated List, and made recommendations with regard to these issues.

These and a number of other papers and reports were discussed at various events hosted by interested States during fall 2009. Belgium held a "Seminar on Strengthening the UN Targeted Sanctions through Fair and Clear Procedures" in Brussels. In the same vein, the Permanent Missions of Switzerland and Finland to the UN organized workshops in New York. These meetings were attended by representatives of interested States, academic institutions and by members of the SC, and therefore provided a fertile ground for discussing the challenges the sanctions regime has been facing, as well as the various options for improving the system.

Timely before the start of the negotiations of the new resolution, in November 2009, the Permanent Mission of Mexico to the UN organized a so-called "Arria-Formula Meeting" ${ }^{63}$ in the SC. In presence of President Mary Robinson and Hina Jilani of the Eminent Jurists Panel, the Council discussed the study of the International Commission of Jurists on the impact of counter-terrorism measures vis-à-vis the respect for human rights, ${ }^{64}$ in particular with regard to the three SC Committees dealing with terrorism. ${ }^{65}$

${ }^{62}$ Cortright, David et al., Human Rights and Targeted Sanctions: an Action Agenda for Strengthening Due Process Procedures, Fourth Freedom Forum and Kroc Institute for International Peace Studies at the University of Notre Dame, 2009.

${ }^{63}$ An "Arria Formula Meeting" is an established practice of the United Nations Security Council named after Ambassador Diego Arria of Venezuela that allows SC members to invite non-state actors and NGOs to participate in SC meetings - otherwise restricted to governments and United Nations officials - under a flexible and informal format. See UN document, S/2010/507, para. 65.

${ }^{64}$ International Commission of Jurists, Assessing Damage, Urging Action, Report of the Eminent Jurists Panel on Terrorism, Counter-terrorism and Human Rights, 2009.

${ }^{65}$ See supra notes 15 and 16 and accompanying text. 
Within the 1267 Committee, discussions about the challenges the regime has been facing and the need for further improvements have taken place at several instances. The Monitoring Team issued its 10 th report ${ }^{66}$ on 31 July 2009, in which it addressed the legal challenges to the sanctions regime, in particular those stemming from European courts. The Monitoring Team referred to various reform proposals made so far, such as the independent and quasi-judicial review panel for de-listing requests proposed by the group of like-minded States, or the idea of an Ombudsperson reviewing de-listing requests as proposed by Denmark in 2005. Another option mentioned in the report was an expanded role for the Monitoring Team itself in order to review de-listing requests and provide the Committee with an analysis of available information with regard to a listed individual or entity. Furthermore, the Team recommended improving the de-listing mechanisms by introducing further elements of transparency and procedural protection. Concrete proposals included a methodical review of each de-listing request and time limitations for individual listings. The 1267 Committee examined this timely report thoroughly in autumn 2009, just before the start of the negotiations of the new resolution.

The Austrian Chairman of the Committee ${ }^{67}$ encouraged a critical internal debate about the status of the regime, its shortfalls and necessary further improvements of its procedures. To this end, the Chairman pro-actively raised awareness about the legal challenges, which EU and other member States were facing, and contributed to the discussions about possible solutions. ${ }^{68}$ This approach in chairing the 1267 Committee can be seen as a continuation of Austria's broader initiative on the Security Council and the rule of law, started in $2004 .{ }^{69}$

${ }^{66}$ See UN Doc, S/2009/502, available at: http://www.un.org/sc/committees/1267/moni toringteam.shtml (last visited 28 November 2010).

${ }^{67}$ The Committee was chaired by the Permanent Representative of Austria to the UN, Ambassador Thomas Mayr-Harting, during Austria's non-permanent biennium 2009-2010.

68 See statements of the Chairman to the Security Council: http: / /www.un.org/sc/commit tees/1267/chairmanbriefings.shtml (last visited 28 November 2010).

69 Federal Ministry for European and International Affairs \& Institute for International Law and Justice, New York University School of Law, The UN Security Council and the Rule of Law: The Role of the Security Council in Strengthening a Rules-based International System. Final Report and Recommendations from the Austrian Initiative, 2004-2008, available at: http://www. 
The Chairman also initiated a visit together with representatives of the Committee to Brussels, Belgium, in October 2009, in order to discuss the latest developments with regard to sanctions' implementation by the EU, following the ruling of the ECJ on Kadi I. In response to this judgment, the European Commission and the Council had revised the relevant EU Council regulation. ${ }^{70}$ The new procedure places greater emphasis on the right of the concerned individual or entity to be heard and to present his/her view to the European Commission, which, on the basis of that information, would conduct an internal ex-post review of the relevant listing. Ultimately, in cases where it would be found that a listing is not sufficiently substantiated and where the EU Council would not find the necessary majority to agree to retain the listing, the new regulation includes the possibility for the Commission, as ultima ratio, to unilaterally proceed with a de-listing of a name from the EU sanctions list.

The exchange with the EU Institutions made clear that, while EU member States needed to find ways to ensure that they were in a position to implement the binding decisions of the SC in accordance with their obligations under the UN Charter, the Committee equally had to look into an improvement of its listing and de-listing procedures. Otherwise, EU member States would risk a systematic annulment by their Courts of EC regulations implementing UN listings because of continued violations of due process rights, particularly the right of defence. The upcoming negotiations of a new resolution provided the opportunity to prevent, or at least mitigate, such a scenario.

Given that SC sanctions have no direct effect on targeted individuals and entities, and that the Council depends on States' implementation, it was clearly in the interest of both sides to avoid a "worst case scenario". In this sense, the Chairman stressed at several occasions that it was essential to continue to improve the Committee's procedures in order to make the 1267 sanctions regime a stronger and more efficient tool. At an open briefing to the SC on 13 November 2009, the Chairman, with the consent of the Committee, reiterated that "the successor resolution

bmeia.gv.at/fileadmin/user_upload/bmeia/media/Vertretungsbehoerden/OV_New_York/FINAL_Re port_-_The_UN_Security_Council_and_the_Rule_of_Law.pdf (last visited 28 November 2010).

70 See supra note 25. 
to resolution 1822 (2008), which was due at the end of 2009, would provide the next opportunity to take further steps towards ensuring fair and clear procedures, improving the working methods and thus strengthening the regime". ${ }^{71}$

When the United States (US), which is the lead country for SC resolutions related to counter-terrorism, presented its draft for a new resolution to the other Council members at the beginning of December 2009 , it was clear that this draft was a serious effort to implement the new approach of President Barack Obama's counter-terrorism policy of rejecting "the false choice between safety and ideals". ${ }^{72}$ This very ambitious draft, with which the US aimed at reaffirming the global consensus against the threat stemming from Al-Qaida and the Taliban by way of increasing the implementation of the sanctions measures and, at the same time, of improving fair and clear procedures, already contained the major elements of resolution 1904, in particular the new de-listing procedures and the establishment of the institution of the Ombudsperson.

Although the first draft was prepared and presented by a P5, the preparation and negotiation process of this resolution is an outstanding example of how, under certain constellations, non-permanent members can coalesce and exert influence in the SC, in particular within its Committees. In this case, the joint and proactive efforts of Austria, Costa Rica and Mexico to further improve the legitimacy and transparency of the regime and to introduce relevant elements of due process fundamentally contributed to the results of resolution 1904.

\section{RESOLUTION 1904 AND THE OMBUDSPERSON}

Security Council resolution 1904, which was unanimously adopted on 17 December 2009, substantially improves the procedures of the 1267 sanctions regime in terms of due process, and thus constitutes a major shift in the UN sanctions system. The resolution reformed key proce-

${ }^{71}$ See UN document, S/PV.6217.

72 President Barack Obama's Inaugural Address, available at: http: / /www. whitehouse.gov / blog/inaugural-address (last visited 30 November 2010). 
dural aspects of the 1267 Committee and includes several proposals made in the various papers and discussion fora described above.

Several provisions were introduced in order to improve the quality of listings and to increase transparency. In order to receive as much relevant information as possible, States are now requested to provide sufficient identifying information. ${ }^{73}$ As a new rule, all parts of the statement of case are publicly releasable, upon request, except for those parts, which the concerned designating States identify as being confidential. Previously, the statement of case had been confidential except for those parts, which were identified as being publicly releasable (OP 11). To improve the listing procedure and thus the quality of the Consolidated List, the period of time for consideration by Committee members was extended from 5 to 10 days and Committee members and the Monitoring Team are called upon to share information which may be useful for the Committee's decision on the listing (OP 16 and 17). An additional important improvement relates to the publication of the narrative summaries of reasons for listing. These have to be made publicly available at the same time a name is added to the list (OP 14). To increase cooperation and information exchange with member States, States are encouraged to appoint a national focal point regarding entries on the Consolidated List (OP 8).

To ensure that the Consolidated List remains accurate, up-to-date and dynamic, additional reviews which address the main weaknesses of the list were introduced. The presence of deceased persons on the list has been one of the major points of criticism. Therefore, a review of deceased persons will be conducted every six months (OP 26). The resolution also directs that an annual review of entries that lack necessary identifiers is carried out, in order to ensure effective implementation (OP 31). Finally, the provision of resolution 1822 (2009), prescribing the conduct of an annual review of the names on the Consolidated List, which have not been reviewed in three or more years, has been reaffirmed (OP 32). To enhance information sharing, States and relevant international organizations are encouraged to inform the Committee of any relevant court decisions and judicial proceedings, which the Com-

\footnotetext{
73 See UN Doc, S/RES/ 1904 (2009), op 13. Hereinafter, references to the different paragraphs and annexes of this resolution will be made in parentheses directly in the text.
} 
mittee can consider during the review of the names or use for updates of narrative summaries (OP 15).

Another procedural improvement concerns the pending issues ("holds"). Committee members have the possibility to place ("technical") holds on matters which are under consideration (e.g. listing or delisting requests but also requests for humanitarian exemptions). Until resolution 1904, there was no clear procedure and no time-limit for such "holds". Therefore, some decisions have been pending before the Committee for several years. With the new resolution, "holds" have a time-limit of 6 months, and this period can only be extended on a caseby-case basis and in extraordinary circumstances (OP 41). The Committee's Guidelines are very clear in limiting the additional final period up to three months. ${ }^{74}$

As has been reiterated along these lines, the most significant innovation of resolution 1904 is the establishment of an impartial and independent Ombudsperson who replaces the focal point for de-listing. It is important to underline that the former has been created solely for the 1267 regime, the focal point thus remaining in place for the other sanction Committees of the SC. For the first time ever, individuals and entities listed by a UN sanctions regime have the opportunity to present their cases before an impartial and independent body, appointed by the Secretary-General. The resolution prescribes that the Ombudsperson shall be an "eminent individual of high moral character, impartiality and integrity with high qualification and experience in relevant fields, such as legal, human rights, counter- terrorism and sanctions... the Ombudsperson shall perform these tasks in an independent and impartial manner...” (OP 20).

The mandate of the Office of the Ombudsperson, who shall receive de-listing requests submitted by or on behalf of listed individuals, groups, undertakings or entities, is laid out in detail in Annex II of the resolution. The tasks of the Ombudsperson consist of the following elements: First, the Ombudsperson shall gather all information relevant from the members of the Committee, the designating State(s), the State(s) of residence, nationality or incorporation, or other relevant

\footnotetext{
${ }^{74}$ See supra note 20.
} 
States, relevant UN bodies and the Monitoring Team. It may engage in dialogue with these States in order to determine their opinions on the de-listing request and shall communicate questions or requests for clarifications from these States to the petitioner. At the end of this twomonth period, the Ombudsperson shall present a written update to the members of the Committee, and then facilitate a two-month period of engagement, including dialogue with the petitioner. This new institution opens up a communication avenue between the relevant States and the petitioner. Instead of processing information in the form of a oneway street, it establishes a true dialogue and exchange of information with the involved parties.

Contrary to various proposals for an independent review panel and the original idea of the Ombudsperson, the institution established in resolution 1904 cannot put forward recommendations to the Committee. However, it will submit a Comprehensive Report, which will summarize all information available, and, based on the analysis of this information, will lay out to the Committee the principal arguments concerning the de-listing request. This language was drafted very cautiously, giving the Ombudsperson room for manoeuvre. If used properly and handled carefully, it can be argued that this mandate gives room for quasi-recommendations. Nevertheless, the final decision stays within the Committee, which will consider and discuss the Comprehensive Report with the Ombudsperson before taking a decision on the delisting request. This decision will be taken —as any other decision in the Committee - by consensus.

The impact of the Ombudsperson, who was appointed by the Secretary-General in close consultation with the Committee on 3 June $2010,{ }^{75}$ remains to be seen. It is nonetheless already safe to state that by choosing an Ombudsperson with outstanding legal and counter-terrorism related qualifications, the Committee took this decision seriously and contributed to the establishment of a serious and meaningful new institution.

75 See, Letter dated 3 June 2010 from the Secretary-General addressed to the President of the Security Council, UN Doc, S/2010/282, 4 June 2010. Kimberly Prost, a Canadian national and former ad litem judge of the International Criminal Tribunal for the former Yugoslavia (ICTY), was appointed Ombudsperson by the Secretary-General. 
Another important improvement is the requirement for further information in case a de-listing request is rejected. The resolution does not foresee to provide "reasons" for rejecting a de-listing request —an issue which has also been a point of criticism by courts - but directs the Committee to convey to the petitioner, through the Ombudsperson, its decision, including, as appropriate, explanatory comments, any further relevant information about the decision and an updated narrative summary of reasons for listing. The Committee's Guidelines, which were adapted pursuant to resolution 1904 (version of 22 July 2010), ${ }^{76}$ introduced the same level of information sharing for de-listing requests submitted by member States directly to the Committee.

It is important to note that for de-listing requests submitted by States, the resolution calls on Committee members to make every effort to provide their reasons for objecting such requests (OP 25). Although this sharing of reasons might stay within the Committee, it is an important step because so far Committee members had not been required to give any reasons for their decisions. Therefore, most de-listing requests were rejected with a simple "no". Another Committee-internal element, which touches upon the question of decision-making, is the possibility of including listing or de-listing requests on the agenda of the Committee and discuss them during the meetings (OP 17 and 22). This new provision enhances a more deliberative listing and de-listing process, ${ }^{77}$ which could contribute to more robust and transparent decision-making processes in comparison to the previous procedure of dealing with such requests exclusively in a written silence (or "no-objection") procedure. In this context, it is worth mentioning the effect of the comprehensive review undertaken pursuant to resolution 1822 (2008), ${ }^{78}$ during which

76 See supra note 20.

77 See Cortright, David et al., Human Rights and Targeted Sanctions: An Action Agenda for Strengthening Due Process Procedures, Fourth Freedom Forum and Kroc Institute for International Peace Studies at the University of Notre Dame, 2009, p. 11.

78 "Directs the Committee to conduct a review of all names on the Consolidated List at the date of adoption of this resolution by 30 June 2010 in which the relevant names are circulated to the designating states and states of residence and/or citizenship, where known, pursuant to the procedures set forth in the Committee guidelines, in order to ensure the Consolidated List is as updated and accurate as possible and to confirm that listing remains appropriate;". See UN Doc, S/RES/1822, op. 25. 
all entries on the Consolidated List have been discussed thoroughly on a case-by-case basis. The process of discussing all the names on the list and considering all available information including possible de-listing requests in the framework of Committee meetings, contributed to a new, more discussion-oriented approach, and created a climate which was favourable for the negotiations of the new resolution and might have also positive effects on how the Committee will deal with new de-listing requests, in particular those presented by the Ombudsperson in future.

Resolution 1904 meets several minimum due process standards, as requested by courts and as defined by former UN Secretary-General Kofi Annan. In 2006, further to the request made in the World Summit Outcome of 2005, ${ }^{79}$ the Secretary-General conveyed his views in an informal paper to the SC and defined four minimum standards required to ensure fair and clear procedures for targeted sanctions ${ }^{80}$ : the right to be informed, the right to be heard by the relevant decision-making body, the right of review by an effective (i.e. impartial, independent and able to provide effective remedy) mechanism, and a periodic review of the sanctions measures. The provision of resolution 1904, directing that narrative summaries of reasons for listing are made available at the time of listing (OP 14), and the additional task of the Ombudsperson to notify, where address is known, individuals or entities about their status of listing, is directly related to the requirement of the right to be informed. The function of the Ombudsperson also provides for the right to be heard. Arguably, the access to an independent and impartial mechanism of review is covered by the new institution. However, the effectiveness of the Ombudsperson is clearly limited, since the competences granted to it do not include the powers to provide effective remedy, such as the lifting of the respective measure or any sort of com-

79 See supra note 22 and accompanying text.

80 The letter by Secretary-General Kofi Annan dated 15 June 2006 has not been published but was referred to in the Security Council debate on 22 June 2006: see UN Doc, S/PV.5474 (2006), p. 5. These criteria are very similar to those elaborated by Prof. Fassbender in the study commissioned by the Legal Counsel of the UN and which was finalized a couple of months before the said debate. See supra note 55 and accompanying text. 
pensation. The request for periodic reviews is covered both by resolution 1822 (2008) and resolution 1904.

\section{SOME INITIAL REACTIONS}

In a statement made shortly before the start of the negotiations that resulted in the adoption of resolution 1904, the representative of Switzerland made the following appeal to the SC:

Member States' Governments find themselves in a serious dilemma when parliaments or courts challenge the legality of domestic measures that implement United Nations targeted sanctions. Member States today may risk having to choose between the option of satisfying obligations imposed by the Charter, or acting in conformity with decisions of their parliaments or courts upholding human rights. The Council could still remedy this problem if it introduced the necessary changes. If it does not, there is a risk of uneven application of United Nations sanctions, which would undermine the credibility and efficiency of the entire system. ${ }^{81}$

The Swiss representative was referring to a proposal which was being discussed at that moment by the National Parliament of Switzerland (Bundesversammlung), and which requested the government (or Federal Council - Bundesrat) to cease implementing sanctions against individuals included on the 1267 list in cases where certain criteria had not been considered. ${ }^{82}$ Hence, even before its adoption, it was clear that resolution 1904 would become the subject of a rigorous scrutiny, involving this time not only tribunals but also legislative organs. On 4 March

81 See UN Doc, S/PV.6217, 13 November 2009, p. 28.

82 The motion was introduced for its consideration in June 2006 by MP Marty Dick. At the time of the statement in the SC it had already been approved by the upper house, the Ständerat, still waiting for the approval by the lower house, the Nationalrat. See 09.3719-Amtliches Bulletin, Ständerat - Herbstsession 2009 - Zweite Sitzung - 08.09.09-08h15, available at: http: / / www.parlament.ch/ab/frameset/d/s/4811/306539/d_s_4811_306539_306688. htm (last visited 30 November 2010). 
2010, the initiative was finally approved by the lower house and adopted as a motion of the Swiss Parliament. ${ }^{83}$ According to it, as of the end of 2010, the Federal Council

will no longer be applying the sanctions taken against physical persons on the basis of the resolutions adopted in the name of the fight against terrorism in so far as:

- The persons concerned have been on the "black list" for more than three years and have not been handed over to the justice system.

- They have been deprived of the right to address an appeal to an independent instance.

- No accusation has been brought against them by a judicial authority; and

- No new incriminating element has been brought forward since their inscription on the list. ${ }^{84}$

It is true that this motion was drafted well before the adoption of resolution 1904. Yet, the Swiss Parliament did not see the need to withdraw from it, or at least to modify it, after December 2009, thereby demonstrating that the amendments introduced by resolution 1904 were not considered sufficient to silence some of the most pressing concerns voiced over the past years. That this motion does not necessarily reflect the view of the Swiss government is as clear as the fact that the latter cannot ignore domestic political pressures of this kind. This was an early indication that the procedural improvements of resolution 1904 notwithstanding, States would still be facing serious challenges by implementing Chapter VII obligations related to targeted sanctions. So, how have States reacted so far to these developments?

The open debate on "the promotion and strengthening of the rule of law in the maintenance of international peace and security", held in June 2010 under the Mexican Presidency of the SC, ${ }^{85}$ proved to be a

83 09.371-Amtliches Bulletin, Nationalrat-Frühjahrssession 2010-Fünfte Sitzung-04.03.1008h00, available at: http://www.parlament.ch/ab/frameset/d/n/4813/320207/d_n_4813_32 0207_320286.htm (last visited 30 November 2010).

${ }^{84}$ See http://www.parlament.ch/d/suche/seiten/geschaefte.aspx?gesch_id=20093719 (last visited 30 November 2010).

85 See Letter dated 18 June 2010 from the Permanent Representative of Mexico to the United Nations, Ambassador Claude Heller, addressed to the Secretary-General, contained in UN Doc, 
good opportunity for States to express their initial reactions to these developments. Practically all participants referred to resolution 1904 and welcomed the recent appointment of the Ombudsperson, underlining the substantial improvements in the listing and de-listing procedures of the 1267 sanctions regime. ${ }^{86}$ While some States preferred to emphasize the accomplishments, ${ }^{87}$ many others noted that further efforts are still needed in order to fully respect fundamental freedoms and human rights, and that sanctions procedures have to be kept under constant review. ${ }^{88}$ In this vein, Norway reiterated the proposal of the like-minded group regarding an independent review panel, ${ }^{89}$ whilst Mexico explicitly mentioned that "the right to an effective remedy is still pending". ${ }^{90}$

The fact that these statements were made in the frame of a rule of law debate show that for various States resolution 1904 and the establishment of the institution of the Ombudsperson represent a commendable effort by the SC to submit its own actions to international law, and especially to move closer towards the respect of human rights when its actions go beyond the traditional inter-State sphere, affecting individuals' rights. Moreover, the creation of an independent institution which is meant to perform a revision of decisions taken by a Council's subsidiary organ can be seen as an exercise in self-restraint. However insufficient, this denotes a new openness of the SC in regard to its traditional hermetic self-comprehension as being "the master of its own decisions".

S/2010/322, 21 June 2010.

${ }^{86}$ See UN Doc, S/PV.6347 \& S/PV.6347 (Resumption 1).

${ }^{87}$ The following statements can be identified among these lines: Australia, France, Germany and the United Kingdom. See UN Doc, S/PV.6347, pp. 15, 19 \& UN Doc, S/PV.6347 (Resumption 1), pp. 8, 19. It is interesting to note that Russia showed a more conservative approach by explicitly discouraging further steps. China made a more general statement on the need to making a more cautious use of sanctions, while the US remained silent altogether on this issue. See UN Doc, S/PV.6347, pp. 21-25.

${ }^{88}$ See, inter alia, the statements by Argentina, Brazil, Denmark, Finland, Lebanon, Liechtenstein, Mexico, Norway, Peru, South Africa and Switzerland. See, UN Doc, S/PV.634, pp. 8, 16, 20-21 \& UN Doc, S/PV.6347 (Resumption 1), pp. 2, 5, 7, 11, 13, $15-16$.

${ }^{89}$ UN Doc, S/PV.6347 (Resumption 1), p. 13. On this proposal, see supra 52 and accompanying text.

90 UN Doc, S/PV.634, p. 8. 
The representative of Liechtenstein put this very clearly: "The approach taken in that resolution may not be perfect and may not take relevant standards of due process to their ultimate consequence, but it is an expression of the political will within the Council to address the legitimate criticisms that had long been expressed against the old system". ${ }^{91}$

The perception that the improvements of resolution 1904 are to be welcomed was shared by the Supreme Court of the United Kingdom (UK) in its judgment of 27 January 2010 on the case Ahmed and others. However, not being the role of a court of law to appraise the Council's political will, but instead to focus on the effective protection of affected rights, it immediately added that despite the establishment of the Ombudsperson and the reforms introduced to the de-listing procedures in Annex II of the resolution, "the fact remains that there... still is not, any effective judicial remedy". ${ }^{92}$

The most recent judicial reaction to these evolutions can be found in the judgment of the GCEU of 30 September 2010 regarding the case Yassin Abdullah Kadi v. European Commission, ${ }^{93}$ also known as the "Kadi II case". The General Court annulled the EC regulation, adopted by the Commission in response to the ECJ's decision in Kadi $I,{ }^{94}$ in so far as it concerns Mr. Kadi. The GCEU arrived at the conclusions that the Commission only observed Mr. Kadi's rights of defence "in the most formal and superficial sense", ${ }^{95}$ and that the review carried out by the Commission equalled a mere "simulacrum", ${ }^{96}$ constituting, hence, a breach of Mr. Kadi's rights of defence and effective judicial review. ${ }^{97}$ Even more

91 See UN Doc, S/PV.6347 (Resumption 1), p. 7.

92 UK Supreme Court, Her Majesty's Treasury (Respondent) v Mohammed Jabar Ahmed and others (FC) (Appellants); Her Majesty's Treasury (Respondent) v Mohammed al-Ghabra (FC) (Appellant); R (on the application of Hani El Sayed Sabaei Youssef) (Respondent) $v$ Her Majesty'sTreasury (Appellant) [2010] UKSC 2, 27 January 2010, available at: http://www.supremecourt.gov.uk/decided-cases/ docs/UKSC_2009_0016_Judgment.pdf (last visited 30 November 2010), para. 78. See, also, idem paras. 181 and 239.

93 See supra note 12.

94 See supra note 42.

95 Supra note 12, para. 171.

${ }_{96}$ Idem, para. 123.

97 See idem, paras. 179-188. The GCEU furthermore decided that the EC Regulation breached the principle of proportionality in relation to Mr. Kadi's right to respect for prop- 
importantly in the present context are the determinations of jurisdiction made by the GCEU, and which are directly based on Kadi I. The General Court reaffirmed its own task to ensure "in principle full review of the lawfulness of the contested regulation in the light of fundamental freedoms, without affording the regulation any immunity from jurisdiction on the ground that it gives effect to resolutions adopted by the Security Council under Chapter VII of the Charter of the United Nations". ${ }^{98}$ Also in line with Kadi I, it further made the point that "that must remain the case, at the very least, so long as the re-examination procedure operated by the Sanctions Committee clearly fails to offer guarantees of effective judicial protection". ${ }^{99}$

This is clearly a restatement of the Solange-argument advanced by the ECJ two years before. ${ }^{100}$ It is true that the GCEU acknowledged that the criticisms raised by EU institutions and governments against Kadi I "were not entirely without foundation", ${ }^{101}$ referring, inter alia, to the "risk that the system of sanctions put in place by the United Nations in the context of the fight against terrorism would be disrupted if judicial review of the kind advocated in the light of the judgment of the Court in Kadi [I] were instituted at the national or regional level", ${ }^{102}$ as well as to the doubts voiced in legal circles regarding the consistency of Kadi I with Articles 25 and 103 of the UN Charter. ${ }^{103}$ At the same time, however, the GCEU not only followed Kadi I due to the respect of judicial hierarchy and of the appellate principle, but also referred to other national courts that have followed the approach of the ECJ, like the Federal Court of Canada in the Abdelrazik case of 4 June $2009^{104}$ and

erty. See idem, paras. 192-195.

98 Idem, para 126.

99 Idem, para 127, emphasize added.

100 See supra note 51 and accompanying text.

101 Supra note 12, para. 121.

102 Idem, para. 113.

103 See idem, para. 115.

104 See Federal Court of Canada, Abdelrazik v. Canada (Minister of Foreign Affairs), 2009, FC 580, [2010] 1 F.C.R. 267, available at: http://www.canlii.org/en/ca/fct/ doc/2009/2009fc580/2009fc580.pdf (last visited 30 November 2010). In what is arguably the most illustrative judicial utterance in connection to the 1267 regime, the Canadian Court noted in this judgment that a listed person is in situation "not unlike that of Josef K. in Kafka's 
the judgment of the UK Supreme Court commented above. ${ }^{105}$ Most strikingly, the GCEU went even further than the ECJ by determining that "once there is acceptance of the premiss, laid down by the judgment of the Court of Justice in Kadi [I], that freezing measures such as those at issue in this instance enjoy no immunity from jurisdiction merely because they are intended to give effect to resolutions adopted by the Security Council under Chapter VII of the Charter of the United Nations, the principle of a full and rigorous judicial review of such measures is all the more justified given that such measures have a marked and long-lasting effect on the fundamental rights of the persons concerned”. ${ }^{106}$

Although in an obiter dictum, it is very significant that the GCEU found it necessary to refer to resolution 1904 and the Ombudsperson in this regard, observing that:

The considerations in this respect, set out by the Court of Justice at paragraphs 323 to 325 of Kadi, in particular with regard to the focal point, remain fundamentally valid today, even if account is taken of the 'Office of the Ombudsperson', the creation of which was decided in principle by Resolution 1904 (2009) and which has very recently been set up. In essence, the Security Council has still not deemed it appropriate to establish an independent and impartial body responsible for hearing and determining, as regards matters of law and fact, actions against individual decisions taken by the Sanctions Committee. Furthermore, neither the focal point mechanism nor the Office of the Ombusdperson affects the principle that removal of a person from the Sanctions Committee's list requires consensus within the committee. Moreover, the evidence which may be disclosed to the person concerned continues to be a matter entirely at the discretion of the State which proposed that he be included on the Sanctions Committee's list and there is no mechanism to ensure that sufficient information be made available to the person concerned in order to allow him to defend himself effectively (he need not even be informed of the identity of the State which has requested his inclusion on the Sanctions Committee's list).

The Trial, who awakens one morning and, for reasons never revealed to him or the reader, is arrested and prosecuted for an unspecified crime”. Idem, para. 53.

105 See supra note 92 and accompanying text.

106 See supra note 12, para. 151. Emphasis added. 
For those reasons at least, the creation of the focal point and the Office of the Ombudsperson cannot be equated with the provision of an effective judicial procedure for review of decisions of the Sanctions Committee. ${ }^{107}$

By making these observations, the GCEU referred once again to the UK Supreme Court in Ahmed and others, ${ }^{108}$ engaging thus in an interesting exercise of inter-judicial dialogue. ${ }^{109}$ According to these two obiter dicta the right to an effective review remains a fundamental challenge to the 1267 sanctions regime, and it is highly probable that this judicial tendency will continue as long as the SC does not fully satisfy the requirements of due process or "fair and clear procedures".

\section{CONCLUSION}

Given that little time has passed since the Ombudsperson took office, it is premature to jump to conclusions at this moment. At the time of writing, no case has been substantiated so far and, therefore, no comprehensive report has been presented to the Committee. As has been argued above, it remains to be seen if the Ombudsperson's observations can amount in practice to actual recommendations. This being said, initial reactions by States, regional and national courts and, in one case, a domestic legislative organ show some persistent preoccupations and interesting evolutions.

This contribution has tried to show that resolution 1904 introduced a series of procedural improvements to the Al-Qaida and Taliban sanctions regime, bringing its de-listing procedures definitely closer to some of the demands of legitimacy, transparency and fairness voiced

${ }^{107}$ Idem, para. 128.

108 See ibidem.

109 For an overview of contemporary inter-judicial dialogue on global affairs including counter-terrorism, and its possible implications for the global legal order, see Benvenisti, Eyal, Reclaiming Democracy: The Strategic Uses of Foreign and International Law by National Courts, AJIL, Vol. 102, 2008, at pp. 241-274; Benvenisti, Eyal and Downs, George W., National Courts, Domestic Democracy, and the Evolution of International Law, EJIL, Vol. 20, at 59/72. Specifically on the dialogue among EU and UK courts following Kadi I, see supra note 50, pp. 14-19. 
in the past five years or so. States, courts and commentators ${ }^{110}$ agree that these reforms are to be welcomed. Most of these reactions show, however, another common pattern: full respect for due process rights is still pending and will remain a fundamental challenge to the sanctions regime of the $\mathrm{SC}$ as long as the right of defence and the right to an effective review, including an effective remedy, are not satisfied according to international legal standards. Nevertheless, the progress that has been achieved through the establishment of the Office of the Ombudsperson should not be underestimated, especially in the broader context of the international or - perhaps more accurately — global rule of law.

By adopting decisions that affect individuals and private entities in concrete cases, the SC functions in many ways similar to national administrative institutions. Just as the traditional function of national administrative law consists in developing mechanisms which exert control over and enable accountability of executive discretion, resolution 1904 can be regarded as a means by which the SC finally recognized that its global regulation activities have to be accompanied by measures which provide for accountability, transparency and voice. ${ }^{111}$ This recognition by the "sovereign" falls short of meeting with fundamental legal standards, but it represents a paradigm shift in the history of the SC, and has opened the path for a continuing review of its discretional powers. In the words of Martin Shapiro, it can be regarded as the start of "an endless game of catch-up in which previously granted discretions are brought under rules, even as new discretions are granted, and no discretion is ever completely and finally reduced to rules". ${ }^{112}$

110 See, inter alia, Cotright, David and de Wet, Erika, Human Rights Standards for Targeted Sanctions, Policy Brief SSRP 1001/01, January 2010, p. 10, available at: http://www.fourthfreedom.org/pdf/10_01_HR_STANDARDS_FINAL_WEB.pdf (last visited 30 November 2010); Antonios Tzanakopoulus, supra note 50, pp. 18-19; Jared Genser and Kate Barth, When Due Process Concerns Become Dangerous:The Security Council's 1267 Regime and the Need for Reform, Boston College International \& Comparative Law Review, Vol. 33, 2010, pp. 1-41, at pp. 40-41.

111 For an introduction to global administrative law, see Benedict Kingsbury, Nico Krisch and Richard B. Stewart, The Emergence of Global Administrative Law, Law \& Contemporary Problems (L\&CP), Vol. 68, 2005, pp. 15-61.

112 Shapiro, Martin, The Institutionalization of European Administrative Space, available at: http: / / www.irle.berkeley.edu/culture/papers/Shapiro.pdf (last visited 30 November 2010). 
At the current stage, the processes that led to the adoption of resolution 1904 and to the establishment of the Ombudsperson are at least as important as the results. This is particularly true as they show that in this scheme of "international composite administration", ${ }^{113}$ the various actors directly and indirectly involved are figuring out multiple and creative ways of demanding legitimate constraints on the global regulatory functions of the SC. National and regional courts are playing a prominent role in this regard. The judicial decisions related to the 1267 regime are a further testimony of what Eyal Benvenisti calls "the emergence of transnational checks and balances", ${ }^{114}$ and demonstrate that inter-judicial dialogue is proving to have indeed the potential "of promoting the ideals of the rule of law in the global sphere". ${ }^{115}$

In this vein, the Solange-argument re-introduced by the ECJ in the context of the 1267 regime and recently reaffirmed by the GCEU in its Kadi II decision is a good example of how "constitutionalization from below" is beginning to take shape in the frame of global governance. Just as the Solange case-law of the Bundesverfassungsgericht contributed enormously to the introduction of fundamental freedoms and human rights at the EU level, the Kadi case-law can be described today "as part of larger efforts to seek constraining constitutional-type norms that impose legal constraints on the Security Council in [the counterterrorism] area". ${ }^{116}$

Political situations of SC members, particularly of the P5, do of course matter. And certain constellations of non-permanent members can make a difference too. More importantly, nonetheless, is the reaction of several UN member States to their courts' decisions, and now in one case to a legislative motion, which challenge their compliance with Chapter VII obligations. It remains to be seen how member States

113 See supra note 39.

114 Benvenisti, Eyal, see supra note 109, p. 271.

115 Benvenisti, Eyal and Downs, George W., see supra note 109, p. 60.

116 Dunoff, Jeffrey L. and Trachtman, Joel P., A functional Approach to International Constitutionalization, in: id. (eds.), Ruling the World?, Constitutionalism, International Law, and Global Governance, Cambridge University Press, Cambridge, 2009, pp. 3-35, at p. 16. The authors underline that the expression "constitutionalization from bellow" was coined by Harold H. Koh. See ibidem, note 18. 
will cooperate with the 1267 Committee after the adoption of resolution 1904. There are strong reasons to believe that the creation of the Ombudsperson will provide good incentives for engagement. On the other hand, if national courts and political bodies continue to assess the insufficiency of the measures adopted in December 2009, States could also tend to have a more cautious attitude and limit cooperation to the absolutely necessary, abstaining, for example, to request further listings. Special attention should be paid to these evolutions as they could be useful indicators of how much the efficiency of sanctions depends on the legitimacy of the decision-making processes.

As of today, it can be said that when several States face similar fundamental concerns of their domestic constituencies, the political power of the SC and Articles 25 and 103 of the UN Charter can no longer be taken as solid guarantees that Chapter VII obligations will be followed without questioning. Common initiatives by groups of like-minded States aimed at reforming the SC sanctions system, and the national positions expressed by various State representatives in international fora, are clear expressions of how UN member States feel compelled to bringing the global level closer to fundamental requirements of the rule of law at the national level. These requirements are often constitutional lato sensu, i.e. they refer to fundamental rights proclaimed in national constitutions and to international human rights law integrated into domestic constitutional systems. Hence, rule of law expectations at the national and international levels are mutually reinforcing goals and programmes, which could prove to be powerful means to overcome the risks of fragmentation inherent in the present debate. ${ }^{117}$ Being a preliminary result of the on-going and pluralistic interplay between these expectations, the Ombudsperson represents a significant achievement in the frame of the emerging global rule of law.

117 See Dyzenhaus, David, The Rule of (Administrative) Law in International Law, L\&CP, vol. 68, 2005, pp. 127-166. 